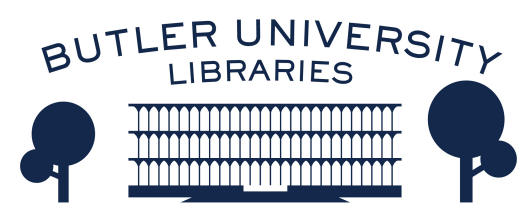

Journal of Hindu-Christian Studies

Volume 5

Article 15

January 1992

\title{
Book Review: "Hindus and Christians: A Century of Protestant Ecumenical Thought"
}

Harold Coward

Follow this and additional works at: https://digitalcommons.butler.edu/jhcs

Part of the Religion Commons

\section{Recommended Citation}

Coward, Harold (1992) "Book Review: "Hindus and Christians: A Century of Protestant Ecumenical Thought"," Journal of Hindu-Christian Studies: Vol. 5, Article 15.

Available at: https://doi.org/10.7825/2164-6279.1068

The Journal of Hindu-Christian Studies is a publication of the Society for Hindu-Christian Studies. The digital version is made available by Digital Commons @ Butler University. For questions about the Journal or the Society, please contact cbauman@butler.edu. For more information about Digital Commons @ Butler University, please contact digitalscholarship@butler.edu. 
religions, background, methods that are different and multifarious. It is a tribute to Fr. Albert's great involvement and at the same time a pointer of hope for the future of Dialogue. It is also a mini 'Who is who?' of the 'Dialogue' world.

Many have used the metaphor of pilgrimage for this attempt at communion and dialogue. A Pilgrim is a free person, the only controlling factor being the holy place or holy water constantly beckoning the pilgrim. It is not a triumphal march but a humble walking, sometimes alone and sometimes in company, accepting on the way what people share with them in their generosity and love. Many pilgrims find themselves having received a vocation within a vocation. While the Catholic Church with its organizational expertise has commissions for inter-religious dialogue there is no institutional back up for groups of other religions where individuals, because of their personal conviction and interest enter into dialogue. Dr. S.R. Jayavelu while critical of institutional or 'guided' dialogue acknowledges the difficulties in inviting the poor, the needy, the downtrodden, the orthodox and even the fundamentalist (195), in an open-ended dialogue.

Mr. C.N. Singaravelu understands dialogue as a meeting and exchange not only of knowledge but also of personal experiences of their own religions (150). Fr. John Peter is convinced 'The bonds that unite us are stronger than the barriers that separate us'
(68). Vandana Mathaji delights in dialoguing with Hindus and never with Hinduism (87). Fr. Bed Griffiths bemoans the lack of openness of the partners of dialogue ("what is there for us to learn?") and so the lack of depth (84). Fr. Gispert contends that 'dialogue is not an escape from the social concern but the means of promoting a just world in the only way it can be promoted in India, by the participation of people of many faiths.' He insists that dialogue is a real need even for the social activist (119). Fr. X. Irudayaraj demands to go beyond the integration of faith and justice to an integration of spirituality Buddhist, Confucian, Islamic, Gandhian, etc. (28).

Dialogue calls for breaking down walls that separate human persons from human persons; it challenges to break down any form of unjust discriminations. There is a poignant story of the conversion of Japanese Buddhists towards their untouchables while there is an insensitivity on the part of Indians to a similar problem (75-77).

While some elaborated practical ways of relating with one another, others have reflected at length on the theme of Dialogue. The fifth part 'Theoretical Reflection' deals with various theological and theoretical underpinnings of the pilgrimage of dialogue.

$$
\begin{aligned}
& \text { D. Jeyaraj, SJ } \\
& \text { Satya Nilayam } \\
& \text { Madras }
\end{aligned}
$$

\section{Hindus and Christians: A Century of Protestant Ecumenical Thought. Wesley Ariarajah. Grand Rapids, Michigan: William B. Eerdmans Pub- lishing Co., 1991, x + 244p. n.p.}

\author{
THIS IS ONLY incidentally a book about \\ Hindus and Christians. Its true title is the sub- \\ title: it is a critical history of the approach of \\ Protestant Christians to other religions from \\ the 1910 World Missionary Conference in \\ Edinburgh up to the present. The author fo-
}

cuses on statements prepared at various World Conferences on Missions such as Jerusalem (1928), Tambaram, India (1938), Mexico City (1963) and Melbourne (1980). He also takes full account of World Council of Churches materials developed at meetings 
such as New Delhi (1961), Addis Ababa (1971), Nairobi (1975), Chiang Mai (1977) and Vancouver (1983). As Director of the WCC Sub-Unit on Dialogue, Wesley Ariarajah is well placed to have carried out this study, and the result is a major contribution to our knowledge of the development of Protestant thought in relation to other religions in the 20th Century.

Ariarajah begins by analyzing the three major missionary conferences at Edinburgh, Jerusalem, and Tambaram that were later incorporated into the World Council of Churches. Although these conferences relate to other religions in general, the author has appropriately chosen to focus his analysis by keeping the spotlight on Protestant attitudes to Hinduism as a case study. Given that many of the leading thinkers early in the century (men like F.N. Farquhar, C.F. Andrews and A.G. Hogg) were missionaries to India, the focus on Protestant approaches to Hinduism is quite appropriate. The author has used as primary sources materials available in the Archives of the WCC including preparatory materials, draft reports, correspondence and minutes of meetings. All of these have been given very careful and detailed analysis. He also consulted books and articles, however his study is in many ways a pioneering work that fills an important gap in our knowledge. It is really the first comprehensive treatment of the subject. The method employed is historical and theological. Historical developments are traced from primary sources and given a balanced theological evaluation at each phase. In addition to the focus on Hinduism the author also selects one or two important persons who played key roles in the discussion, e.g. Nicol Macnicol's presentation at Jerusalem, Hendrick Kraemer's preparatory volume for Tambaram and the contributions of Niles and M.M. Thomas to the post-Tambaram discussions. The result is a clear, interesting and well written volume that has already become a basic reference work on my shelf.

The book is divided into three parts. The first, and most insightful in terms of bringing new knowledge, deals with the three missionary conferences before World War Two at Edinburgh, Jerusalem and Tambaram. Ari- arajah demonstrates that prior to Tambaram in 1938 the attitude to other religions was open and respectful, formulated by missionaries who were in daily contact with believers of other religions. The Edinburgh Conference of 1910 concluded that in carrying the gospel to all religions and all peoples, Christians must be sensitive to the spiritual depths present in other religions. Ariarajah notes that the Edinburgh Conference was remarkable for reaching conclusions that the Christianity of the 1990 s is just beginning to accept: namely, a non-defensive listening attitude, a judging of other religions by their highest teachings rather than their lowest manifestations, and a refusal to judge the truth claims of others as incompatible with the gospel message. These very forward looking conclusions of 1910 had little lasting influence because they were overshadowed by the meeting of missionaries at Tambaram, South India, in 1938. In preparation for the Tambaram meeting Hendrik Kraemer prepared a theological statement on the approach of Christianity to the other religions. Such a statement was needed because of the debate stirred up by W.E. Hocking at the second World Missionary Conference in Jerusalem in 1928. Hocking had maintained that in order to counter the growing secular influence in the world, Christianity should join forces with the other world religions. Hocking represented a developing liberal tradition in the United States which "sought an overall concept of 'Religion' cutting across religious frontiers against the rise of secularism in the world" (p. 49). This American view was strongly opposed by German theologians who rejected any notion of universal religion and the Edinburgh idea of enrichment, and instead emphasized the uniqueness of Christianity that demanded conversion from those who followed other religions. In his preparatory statement, Kraemer followed the lead of the German theologians and then drew heavily on the Continental theologians Karl Barth and Emil Brunner. In so doing Kraemer shifted the discussion from the views evolved through missionary lives lived in intimate contact with other religions (e.g. the views of A.G. Hogg and C.F. Andrews so effectively expressed at Edinburgh in 1910) to the platform of a sys- 
tematic theology being formulated in the heart of Europe by thinkers who had not had intimate contact with other religions. Yet it was the abstract theology of Barth and Brunner that took precedence over the earlier Edinburgh statements of the missionaries who had worked out their Christian response through lifetimes of labouring in the young Christian churches of Asia where Christianity was the minority in the midst of Hindu, Buddhist or other majority traditions. Sitting secure in the center of Europe, it was easy to adopt an absolute and exclusivistic view of the Christian gospel.

Kraemer's preparatory study for Tambaram turned out to be much more than just a pre-conference study statement. Published in 1938 as a complete book, The Christian Message in a Non-Christian World marked the start of a new attitude from Protestant Christians toward other religions. Rather than seeing them as sources of enrichment and deepening (Hogg and Andrews) or as allies against secularism (Hocking), these earlier missionary insights were displaced by Kraemer's strident and exclusivistic call for the conversion of all to the gospel revelation of God in Jesus Christ. This call dominated not only the Tambaram meeting but subsequent thought about other religions within Protestantism from 1938 up until the 1980s. Kraemer distinguished between two types of religions, those founded on revelation (Judaism, Christianity and to a degree Islam) and those having "a primitive apprehension of reality." Kraemer provides a detailed analysis of how this "primitive apprehension of reality" is evidenced in Hinduism with its perception of all opposites as subsumed within a transcendent unity such as rta or ätman-Brahman. Such views, concluded Kraemer, were naturalistic (in that they drew no absolute distinction between humans and nature) and vitalistic (in that religion was seen as a quest for realizing a 'higher' mystical life) (p. 60). Ariarajah points out that in Kraemer's view such approaches to religion were "primitive" in that they were fully outside the revealed religions (with their separation of humans and nature, God and world) and completely discontinuous with the unique revelation of God in Jesus Christ. European civilization, arising from the Christian revelation was judged naturally superior to civilizations based on the "primitive apprehensions" of the other religions. It is ironic that in the 1990 s it is precisely this strong sense of separation between humans and nature that the environmental crisis is calling into question. And in searching within Christianity to find a more sensitive approach, it is often the stimulus of Kraemer's so-called "primitive apprehension" of the Eastern religions that is proving helpful.

Ariarajah observes that Kraemer's presentation of Barthian theology at Tambaram did not go unopposed. The old India-hand A.G. Hogg spoke for many Asian missionaries and leaders of the young Asian churches. Kraemer, said Hogg, states that in the Bible two things are happening: God is revealing himself and flawed humans are apprehending that revelation, witnessing to it, and in so doing distorting it. But, said Hogg, could not the same thing be said for Hinduism. If behind the distorted apprehension of Christianity there was a God who revealed himself, then why, behind the distorted apprehension of Hinduism could there not also be a revelatory presence? The point of Hogg's critique was that just as one could not equate the Christian revelation with its empirical forms, so also one should not equate other religions with their empirical forms-yet this is exactly what Kraemer (following Barth) was doing. In Hogg's view all religions depend on the revealing initiative of God, and Christianity has no basis for a unique claim in this regard.

The 1938 debate between these two views is in many ways still alive. Wilfred Cantwell Smith was deeply influenced by A.G. Hogg, and Smith's "theology of world religions" is an attempt at updating Hogg's view (see especially Smith's Towards a World Theology). On the other hand the evangelical churches of the Lusanne Covenant of 1974 continue to missionize other religions from a rigidly exclusivistic Christian revelation perspective. Ariarajah concludes that the continued meetings of the World Council of Churches and its various sub-units have not significantly advanced the debate. For a long time the effect of Kraemer's theology was to cause the Protes- 


\section{Book Reviews}

tant Churches to withdraw into a shell. Rather than following the open give and take of missionaries early in this century, the middle decades produced a Christianity which, following Kraemer's theology, largely broke off dialogue with other religions. During the 1980s when Protestant thought again began opening itself to dialogue, the comment was often made that others such as Hindus and Buddhists did not seem very interested. Given Ariarajah's review of the history of inter-faith relations during this century, such disinterest to a fresh outburst of "Christian enthusiasm" is not surprising. It is not, as is sometimes suggested, an indication of the superior quality of Christian love. If anything, it is the legacy of its lack!

In Ariarajah's assessment, Protestant Christianity today, while opening itself more to a search for community and partnership (part 2 of the book), is still stuck in the Kraemer-Hogg dilemma. What is needed for the future, Ariarajah argues in part 3, is an authentic Christianity that moves away from a missological explanation of the significance of Christ. A new Christology is needed that would provide a foundation for theology in a context of religious plurality (p. 214). He finds helpful leads to come from Roman Catholic theologians operating in the post Vatican II spirit-thinkers such as Karl Rahner and Raimundo Panikkar.

In this volume, Ariarajah had done much more than just critically review Protestant thinking towards other religions (though that in itself is a significant contribution). In this book he has laid down the foundation and pointed the direction for Christian thought in the future, if it is to advance Christian relations with other religions. All of this is an important achievement. The book's complete and carefully edited Bibliography is a solid resource for any student doing research. My only criticism to both the author and to the publisher, Eerdmans, is that the lack of an Index makes this otherwise very find book much less useful for scholarly research.

\author{
Harold Coward \\ Professor of Religious Studies \\ University of Calgary \\ Calgary, Canada T2N 1N4
}

